Invited Article: Why Professionals Fail to Catch Liars and How They Can Improve

\author{
Aldert Vrij ${ }^{1}$ \\ University of Portsmouth
}

Running head: Lie detection

1 Correspondence concerning this article should be addressed to: Aldert Vrij, University of Portsmouth, Psychology Department, King Henry Building, King Henry 1 Street, Portsmouth PO1 2DY, United Kingdom or via email: aldert.vrij@port.ac.uk 


\begin{abstract}
In the first part of this article, I will briefly review research findings that show that professional lie catchers, such as police officers, are generally rather poor at distinguishing between truths and lies. I believe that there are many reasons contributing towards this poor ability, and will give an overview of these reasons in the second part of this article. I also believe that professionals could become better lie detectors and will explain how in the final part of this article.
\end{abstract}




\section{Invited Article: Why Professionals Fail to Catch Liars and How They Can Improve}

When criminal justice investigators (police officers, lawyers, prosecutors, judges, juries, and so on) assess statements made by suspects, victims and witnesses, they are almost always confronted with the age old dilemma of how to distinguish between those who are telling the truth and those who are not (Horvath, Jayne, \& Buckley, 1994). Police officers like to present themselves as being good lie detectors (Inbau, Reid, Buckley, \& Jayne, 2001), but research does not really support this claim. In a typical lie detection study, professional lie catchers, such as police officers, CIA agents, etc., are shown videoclips from numerous liars and truth tellers and are asked after each clip to indicate whether the person was lying or telling the truth. In such a study, simply guessing would result in an accuracy rate (percentage of correct classifications) of 50\%. Vrij and Mann (in press) reviewed ten lie detection studies with professional lie catchers. Three main findings emerged. The average total accuracy rate (i.e., accuracy scores for detecting truths and detecting lies combined) was rather low, 55\%, and very similar to the total accuracy rate (57\%) found with laypersons, such as college students, as observers (Vrij, 2000a). Also, although professional lie catchers don't seem to be better lie detectors than laypersons, they often feel more confident in their ability to detect truths and lies. Finally, some groups of professional lie catchers are better than others. For example, Ekman and O'Sullivan (1991) found that police officers (56\% total accuracy) and polygraph examiners (56\% total accuracy) obtained similar accuracy rates to university students (53\% total accuracy), whereas members of the Secret Service were better at detecting lies than university students (64\% total accuracy).

However, a limitation of most of these lie detection studies with professional lie catchers is that they are artificial. In those studies, police officers typically have to detect truths and lies told by college students for the sake of the experiment in laboratory settings (e.g., Ekman \& O'Sullivan, 1991; Ekman, O'Sullivan, \& Frank, 1999). This situation differs in at least three ways from detecting truths and lies in police interviews. First, the stakes 
(positive consequences of getting away with the lie and negative consequences of being caught) are lower in those laboratory settings than in police interviews which may hamper lie detection. I return to this stakes issue below. Second, the average college student differs from the average suspect in a police interview. For example, college students are on average more intelligent that suspects in police interviews (Gudjonsson, 2003) and this difference in intelligence might affect the way they tell lies (Ekman \& Frank, 1993). Third, college students in laboratory settings typically lie about different topics (for example, what their attitude is towards the death penalty) than suspects in police interviews. Because of these differences, examining police officers' ability to distinguish between truths and lies told by these students in laboratory settings might not be a valid test of their true ability to detect truths and lies. Our recent study (Mann, Vrij, \& Bull, 2004) was more ecologically valid and therefore a better test to examine police officers' ability to detect deceit. We showed 99 police officers, not identified in previous research as belonging to groups which are superior in lie detection, videotapes consisting of 54 truths and lies told by suspects during their videotaped police interviews. A total accuracy rate of $65 \%$ was obtained, which was higher than generally found in more artificial studies. However, the accuracy rate was still far from perfect, and errors were frequently made. Errors are not surprising given the many difficulties and pitfalls in lie detection which are outlined in the next section.

\section{Difficulties and Pitfalls in Lie Detection ${ }^{1}$}

1. Absence of Pinocchio's nose. Several recent reviews of deception research (Ben-Shakhar \& Elaad, 2003; DePaulo, Lindsay, Malone, Muhlenbruck, Charlton, \& Cooper, 2003; Kleiner, 2002; MacLaren, 2001; Masip, Sporer, Garrido, \& Herrero, in press; Vrij, 2000a; in press, a) in which more than 150 studies regarding how liars respond were analysed, revealed one striking finding: There is not a single verbal, nonverbal or physiological cue uniquely related to deception. In other words, nothing similar to Pinocchio's growing nose actually exists. Obviously, this makes lie detection difficult as there is nothing the lie detector can 
truly rely upon. The absence of giveaway cues does not imply that liars and truth tellers always respond in the same way. In fact, they do not. However, when liars and truth tellers do respond differently, this is not the result of lying per se, but the result of the liar experiencing at least one of the following processes: emotion, content complexity, and attempted control (Vrij, 2000a) ${ }^{2}$. These processes reveal signs that can be detected by a lie detector. Each process emphasises a different aspect of deception and deceptive responses. Liars may well experience all three aspects simultaneously, and the three processes should therefore not be considered as opposing camps.

With regard to emotions, Ekman (1985/2001) pointed out that liars might feel guilty because they are lying, might be afraid of getting caught, or might be excited about having the opportunity to fool someone.

Regarding content complexity, sometimes liars find it difficult to lie, as they have to think of plausible answers, avoid contradicting themselves and tell a lie that is consistent with everything that the observer knows or might find out, whilst avoiding making slips of the tongue. Moreover, they have to remember what they have said, so that they can keep their story consistent when asked to repeat it (Burgoon, Buller, \& Guerrero, 1995; Vrij, 2000a). This might be more difficult than truth telling, especially when the liar has not prepared a story and has to concoct one instantly. Also, liars continuously have to monitor their speech and nonverbal behaviour in order to appear convincing throughout their lie. This probably becomes increasingly difficult as lies increase in length and complexity.

Regarding attempted control, liars may worry that engaging in deceit will increase the likelihood of them exhibiting cues that will give their lies away, and therefore may attempt to control their behaviour, suppressing such signs and engaging in impression management, that is, trying to make a convincing impression in order to avoid getting caught (Buller \& Burgoon, 1996; Hocking \& Leathers, 1980). However, this is not easy. Liars need to effectively suppress nervousness, masking evidence of having to think hard, should know 
how they normally respond in order to make an honest and convincing impression, and should display the responses they want to show. It may well be the case that, when attempting to control their behaviour, liars may exhibit 'overcontrol', that is, displaying a pattern of behaviour that will appear planned, rehearsed, and lacking in spontaneity (DePaulo \& Kirkendol, 1989).

Another possible cue that may result from inadequate control of behaviour is that performances may look flat due to a lack of involvement (Burgoon \& Buller, 1994; DePaulo et al., 2003). Charles Ingram, who was found guilty in the United Kingdom of cheating his way to the top prize in the popular TV quiz 'Who wants to be a Millionaire' might have experienced this. Staff working for the TV programme became suspicious when Ingram and his wife 'had not appeared as jubilant as the newly rich might' after winning the top prize of $£ 1,000,000$ (The Independent, 8 April 2003, page 9). This might have been due to a combination of fear of being caught out coupled with the awareness that their win was not legitimate.

Deception research has revealed evidence for all three processes. For example, compared to truth tellers, liars have a tendency to speak with a higher pitched voice (which might be the result of experienced arousal (emotion)); to include fewer details into their accounts (which might be the result of content complexity); to make fewer illustrators (hand and arm movements designed to modify and/or supplement what is being said verbally), and to make fewer hand and finger movements (non-functional movements of hands and fingers without moving the arms) which might be the result of either content complexity or attempted control.

Perhaps a striking finding in deception research is that clear cues of nervous behaviour, such as gaze aversion and fidgeting, do not appear to be related to deception. This is striking because, as I will address later on, people, including professional lie catchers, strongly believe that liars display such cues of nervousness. However, the lack of such 
behaviours might be the result of the artificial nature of deception studies, which have almost exclusively been conducted in university laboratories where participants (mostly college students) tell the truth or lie for the sake of the experiment. In those situations the stakes are typically low. Participants might receive a nominal financial reward when they lie convincingly but this does not really reflect the vast gains someone might win for lying in some real life situations. A form of punishment (negative consequences) if the liar is caught out is nearly always absent in laboratory studies both for practical ${ }^{3}$ and ethical reasons. In real life liars sometimes face severe negative consequences when they are caught out. Most lies people tell in daily life are low-stakes lies (DePaulo, Kashy, Kirkendol, Wyer, \& Epstein, 1996) and deception studies perhaps quite accurately reflect how people respond in such situations. However, sometimes the stakes are high for liars (and truth tellers), such as in police interviews. It might well be that liars (and truth tellers) behave differently in such situations. Police officers typically believe that guilty suspects will be afraid of getting caught (Inbau et al., 2001), and, if this is true, nervous behaviours might well occur when suspects lie during their police interviews.

Studies examining suspects' behaviour are rare because of three difficulties researchers face. It is not easy for them to get hold of videotaped police interviews. Moreover, it is difficult to establish the ground truth in such interviews, that is, to establish with absolute certainty when the suspect is lying and when the suspect is telling the truth. Finally, in order to make valid comparisons between suspects' lies and truths, videoclips of lies and truths need to be selected which are truly comparable. Selecting so-called comparable truths (Vrij, 2002b) is difficult as I will explain later. In a recent study, we (Mann, Vrij, \&, Bull, 2002) overcame these difficulties and examined the behaviour displayed by 16 suspects during their police interviews. The suspects were all being interviewed in connection with serious crimes such as murder, rape and arson, and all interviews were videotaped. Regarding the ground truth, clips of video footage were selected 
where other sources (reliable witness statements and forensic evidence) provided evidence that the suspect lied or told the truth. In addition, for each suspect, truths and lies were chosen which were as comparable as possible in nature. For example, a suspect who gave a detailed description about how he had assisted in killing a person (truth), later denied any involvement in the crime (lie). Results revealed that like the participants in numerous laboratory studies, the suspects in these high-stakes situations did not show clear stereotypical nervous behaviours such as gaze aversion and fidgeting either. In fact, they exhibited an increase in pauses and (male suspects displayed) a decrease in hand and arm movements. These behaviours are more in line with the content complexity and attempted control approaches than with the emotional approach. The strongest evidence that content complexity affected suspects' behaviour more than nervousness was the finding regarding eye blinks. Suspects made fewer eye blinks when they lied. Research has shown that nervousness results in an increase in eye blinking (Harrigan \& O'Connell, 1996), whereas increased cognitive load results in a decrease in eye blinking (Wallbott \& Scherer, 1991).

The apparent predominance of cognitive load processes compared to emotional processes in our suspect interviews is perhaps not surprising. Many suspects in serious cases have had a history of regular contact with the police. Therefore, they are probably familiar with police interviews which might somewhat decrease their nervousness. However, suspects in police interviews are often less intelligent than the average person (Gudjonsson, 2003). There is evidence that less intelligent people will have particular difficulty in inventing plausible and convincing stories (Ekman \& Frank, 1993).

2. Subtle differences. Differences in behaviour between liars and truth tellers are usually very small (Vrij, 1994) and, obviously, the smaller the differences, the more difficult it will be to detect them. However, cues to deception may be more likely to occur when the three processes which might elicit verbal and behavioural responses to deceit (emotions, cognitive complexity, and attempted behavioural control) become more profound. Indeed, in a series of 
laboratory experiments where the stakes were manipulated (although the stakes were never really high), it was found that high-stakes lies were easier to detect than low-stakes lies (DePaulo, Kirkendol, Tang, \& O'Brien, 1988; DePaulo, Lanier, \& Davis, 1983; DePaulo, LeMay, \& Epstein, 1991; DePaulo, Stone, \& Lassiter, 1985b; Lane \& DePaulo, 1999; Vrij, 2000b; Vrij, Harden, Terry, Edward, \& Bull, 2001), and that motivated liars (liars who really tried to avoid getting caught) were easier to catch than unmotivated liars (DePaulo, Blank, Swaim, \& Hairfield, 1992).

3. The use of heuristics. Rather than actively scrutinising another's reactions for cues to deceit, observers may instead rely on 'rule of thumb' decision rules which are often called cognitive heuristics (Levine, Park, \& McCornack, 1999). Person perception researchers have emphasised that this is the most effective way that observers with limited time and attentional resources deal with complex environments (Macrae \& Bodenhausen, 2001). However, such heuristics easily lead to systematic errors and biases. Levine et al. (1999) refer to several heuristics which are thought to influence veracity judgements, including the probing heuristic and the representativeness heuristic. The probing heuristic (Levine \& McCornack, 2001) refers to judges' tendency to believe a source more after the source has been probed. (Receivers have a strong belief in the efficacy of probing as a lie detection strategy. In case probing does not result in clear signs of deceit, and it often will not (Levine \& McCornack, 2001), the source is more likely to be believed.) The representativeness heuristic (Stiff, Miller, Sleight, Mongeau, Garlick, \& Rogan (1989) refers to the tendency to evaluate a particular reaction as an example of a broader category. Used in a deception context it could explain people's inclination to interpret nervous behaviours as signs of deceptive behaviour. O'Sullivan (2003) demonstrated that the Fundamental Attribution Error (FAE) undermines lie detection. The FAE is the tendency, when forming impressions of others, to overestimate dispositional factors of that person and to underestimate situational factors. Therefore, when an observer believes that someone is generally a trustworthy person, s/he 
will have the tendency to judge that person as truthful in any given situation. Similarly, when the observer believes that someone is an untrustworthy person, s/he will be inclined to judge that person as dishonest in any given situation.

Even more, as yet unlabelled, heuristics might be present in veracity judgements. For example, observers have a tendency to judge reactions which are odd or infrequent (e.g., keeping the eyes closed during a conversation, staring during the conversation, etc.) as deceptive (Bond, Omar, Pitre, Lashley, Skaggs, \& Kirk, 1992). Since Bond et al. (1992) used expectancy violation as a theoretical model for this finding, I would like to call this heuristic the 'expectancy-violation heuristic'. Finally, people with attractive faces are typically thought of as more honest (Aune, Levine, Ching, \& Yoshimoto, 1993; Bull, in press; Bull \& Rumsey, 1988), so are individuals with a baby-faced appearance (Masip, Garrido, \& Herrero, in press, a, b), an heuristic which I would like to call the facial appearance heuristic.

4. Violations of conversation rules. Social conversation rules may hamper lie detection. For example, in daily life conversations it is often seen as inappropriate or strange if the listener asks the other to elaborate on what s/he just said. As I will argue later, such a tactic might help lie detectors. Also, conversation rules determine that a listener looks the speaker in the eye, yet the eyes don't reveal reliable information about deception. As I will point out later, it would benefit the listener if s/he looked at the speaker's body movements or closed his/her eyes and just listened to the speaker when attempting to detect deceit, but this would be viewed as inappropriate in daily life conversations.

5. The wrong cues. There are widespread, but often incorrect, beliefs about how people respond when they lie. Studies investigating how people think liars respond have revealed that observers (both laypersons and professional lie catchers) overwhelmingly expect liars to react nervously, with 'liars look away' and 'liars make grooming gestures' being the most popular beliefs (Akehurst, Köhnken, Vrij, \& Bull, 1996; Lakhani \& Taylor, 2003; Mann et al., 2004; Strömwall \& Granhag, 2003; Taylor \& Vrij, 2000; Vrij \& Semin, 1996; Vrij \& 
Taylor, 2003). For example, 75\% of police officers believe that liars look away ${ }^{4}$ (Mann et al., 2004; Vrij \& Semin, 1996), and make grooming gestures (Vrij \& Semin, 1996). These findings are not surprising given the fact that police manuals typically promote the idea that liars look away and fidget (Gordon, Fleisher, \& Weinberg, 2002; Hess, 1997; Inbau et al., 2001; Yeschke, 1997; Zulawski \& Wicklander, 1993). However, as already mentioned, empirical evidence to support this view is lacking. It is therefore not surprising that in our lie detection study where we showed police officers videoclips of suspects who lied or told the truth during their police interviews (Mann et al., 2004), we found that the more the police officers endorsed the 'lie cues' promoted in police manuals, the worse they became at distinguishing between suspects' truths and lies. In other words, applying the information provided in those manuals appears to be counterproductive.

Apart from being taught the wrong cues, there is another reason why people typically expect nervous reactions: They believe that they show such reactions themselves when they lie. In two studies we investigated participants' behaviour while lying and truth telling, and also asked the participants afterwards to indicate what behaviour they thought they had exhibited when they lied and when they were telling the truth (Vrij, Edward, \& Bull, 2001a; Vrij, Semin, \& Bull, 1996). Results showed that participants had poor insight into their own behaviour and thought that they responded more stereotypically while lying (showing increased gaze aversion, an increase in movements, and so on) than they in fact did. For example, participants actually showed a reduction in movements. In other words, it seems that during lie detection observers look for cues they mistakenly believe they themselves show while lying.

6. Overemphasis on nonverbal cues. Another reason why I think people are typically poor lie detectors is that they don't seem to take speech content enough into account. Observers do listen to the speech content, but mainly in situations where they are knowledgeable about the topic. In that case observers can easily compare their knowledge of facts with what the 
speaker says. In one real life case (the Independent, 20 July 2001, page 3) Jeffrey Archer, a former British politician later convicted for perjury, asked three journalists to leave his hotel room during a political party conference while he took a call from the Prime Minister. Another politician who saw the three journalists pacing up and down the corridor asked them what they were doing. He immediately realised that Archer had lied to the journalists and could not be speaking to the Prime Minister on the phone, because he knew that the Prime Minister was sitting on the conference platform at that very moment. In another real life case (Vrij \& Mann, 2001), police officers asked a man who was suspected of murder about his whereabouts on a certain afternoon. The man explained in detail that he visited a market in a village near his home. The police detectives knew that this was a lie because, apparently unknown to the suspect, the market had been cancelled on that particular day. In both examples lie detectors could discover that the person is lying by comparing what they know with what the target person says. Moreover, when police officers hear different statements from the same person about a topic, or different statements from different people about a topic, they also tend to focus primarily on speech content, checking for consistency between the different statements (Granhag \& Strömwall, 1999, 2000, 2001a, b; Strömwall, Granhag, \& Jonsson, 2003). ${ }^{5}$

However, there is evidence that in situations where there is no information to check and only one statement is made, people, including police officers, primarily pay attention to nonverbal communication in order to form an impression (Greuel, 1992; Mehrabian, 1972; Mehrabian \& Ferris, 1967; Mehrabian \& Wiener, 1967; Rozelle \& Baxter, 1975; Vrij, Foppes, Volger, \& Winkel, 1992; Walkley, 1985; Waltman, 1983). Meissner and Kassin (2002) pointed out that in Florida, Tom Sawyer, believed to be innocent but accused of sexual assault and murder, became a prime suspect because he appeared embarrassed and his face flushed during an initial interview (see Ofshe, 1989, for a detailed description of the Tom Sawyer case). According to Kaufmann, Drevland, Wessel, Overskeid, and Magnussen 
(2003) judicial decisions are sometimes based on nonverbal communication, even when available evidence points in the other direction. They describe a Norwegian court trial in which, in their words (p. 22): "although the circumstantial evidence of guilt was strong, the defendant (a financial adviser) was acquitted partly because......his nonverbal behavior was confident without evasive eye movements of any sort".

There are several reasons why in the latter circumstances people rely so much on nonverbal behaviour. First, it might be more noticeable than speech (DePaulo \& Kirkendol, 1989; Vrij, 2000a). For example, there are automatic links between strongly felt emotions and certain behaviours (Ekman, 1985/2001), whereas there are not such strong links between emotions and speech content. Anger, for example, results in several cues, including narrowing of the lips. This might well give a lie away if an angry person denies being angry.

Second, there is sometimes little speech content to rely upon because the suspect just says a few words or just a couple of sentences. In such situations an observer has almost no choice than to make a judgement based on someone's behaviour.

Third, professional lie catchers may not know which verbal cues to pay attention to even when the target person speaks substantially. They may not know this because police manuals do not pay much attention to verbal aspects of speech, or in the few cases where they do mention verbal cues, they do not focus on the cues which research has indicated are (to some extent) diagnostic for deception (Vrij, 2000a; in press, a). Finally, influential researchers in the deception field, such as Ekman (1985/2001), don't put much emphasis on speech content either. ${ }^{6}$ However, speech content can reveal deception if observers pay attention to the diagnostic cues (Vrij, 2000a; in press, a).

7. People do not take individual differences into account. There are large individual differences in people's speech, behaviour and physiological responses. Some people typically make many movements, whilst others do not; some people are very talkative, others are not, etc.. Another reason why people fail to catch liars is that they do not take such individual 
differences into account when they attempt to detect deceit. Those people whose natural behaviour looks suspicious are in a particularly disadvantageous position. Some individuals' nonverbal behaviour gives the impression that they are telling the truth (honest demeanour bias), whereas others' natural behaviour leaves the impression that they are lying (dishonest demeanour bias) (Riggio, Tucker, \& Throckmorton, 1988; Riggio, Tucker, \& Widaman, 1987; Vrij, 1993; Vrij \& Van Wijngaarden, 1994; Vrij \& Winkel, 1992b; Zuckerman, DeFrank, Hall, Larrance, \& Rosenthal, 1979). Demeanour biases are related to personality traits. Expressive people, for example, exude credibility, regardless of the truth of their assertions. It is not that they are particularly skilled at lying, but their spontaneity tends to disarm suspicion, which makes it easier for them to get away with their lies (Riggio, 1986). On the other hand, people with a strong sense of public self-consciousness tend to make a less credible impression on others, regardless of whether they are telling the truth. When these individuals lie they are concerned about being scrutinised by others, which changes their behaviour in such a way that it appears dishonest. Introverts and socially anxious people also impress others as being less credible. The social clumsiness of introverts and the impression of tension, nervousness or fear that is given off naturally by socially anxious individuals is interpreted by observers as indicators of deception. Interestingly, their demeanour seems not to accurately reflect their behaviour. For example, introverted people lie infrequently (Kashy \& DePaulo, 1996). Introverts also commit fewer crimes than extraverts (Eysenck, 1984). Furthermore, socially anxious people are less likely to persist in lying when challenged (Vrij \& Holland, 1998).

Errors in interpreting someone's behaviour easily arise in cross-cultural interactions due to differences in behaviour displayed by different ethnic groups. Afro-American people generally display more gaze aversion than white American people (LaFrance \& Mayo, 1976), and people originating from Turkey and Morocco who are living in the Netherlands show more gaze aversion than native Dutch people (Vrij, 2000a; Vrij, Dragt, \& Koppelaar, 1992). 
Such differences are, in part, caused by the fact that gaze patterns are influenced by culture, and that looking into the eyes of a conversation partner is regarded as polite in Western cultures but is considered to be rude in several other cultures (Vrij \& Winkel, 1991; Vrij, Winkel, \& Koppelaar, 1991).

Also, compared to Caucasian Dutch citizens, Dutch citizens originating from Surinam, show more gaze aversion, make more speech disturbances (speech fillers such as 'ah', 'um', 'er' and stutters), smile more often, and make more self manipulations (scratching the head, wrists, and so on) and illustrators (hand and arm movements designed to modify and/or supplement what is being said verbally) (Vrij \& Winkel, 1991). These behaviours show an overlap with the behaviours that Western white people associate with deception (Akehurst et al., 1996; Strömwall \& Granhag, 2003; Taylor \& Vrij, 2000; Vrij \& Semin, 1996; Vrij \& Taylor, 2003). Indeed, several experimental studies which we conducted in the Netherlands have revealed that behaviours that are typically displayed by members of some ethnic groups living in the Netherlands make a suspicious impression on Caucasian Dutch police officers, a phenomenon which we labelled cross-cultural nonverbal communication errors (Vrij \& Winkel, 1992a, 1994; Vrij et al., 1991, 1992). That is, nonverbal behavioural patterns that are normal and natural for certain ethnic groups may be interpreted by Caucasian observers as revealing attempts to hide the truth.

8. People do not take situational differences into account. Not only do different people behave differently in the same situation (interpersonal differences), the same person also behaves differently in different situations (intrapersonal differences). Neglecting those intrapersonal differences is another error that lie catchers make. Police officers are advised to examine a suspect's natural, truthful, behaviour during the small-talk part at the beginning of the interview and to compare this behaviour with the behaviour shown by the suspect during the actual interview (Inbau et al., 2001). Differences in behaviour could then be interpreted as signs of deceit. Moston and Engelberg (1993) noticed that this is a technique commonly 
employed in police interviews in England and Wales. Unfortunately, this approach is prone to incorrect judgements because an incongruent comparison is made. Small-talk and the actual investigation are fundamentally different situations. Small-talk conversations are lowstakes situations where the suspect's responses are unlikely to have any negative consequences. The investigative part of the interview, on the other hand, is a high-stakes situation where the suspect's responses are intensely scrutinised and where the suspect's reactions may easily heighten suspicion. Suspects are probably aware of this and therefore, not surprisingly, both guilty and innocent people tend to show different behaviours during small-talk compared to the actual interview (Vrij, 1995). Some researchers make the same mistake. In a rare example of a real life high-stakes deception study, Hirsch and Wolf (2001) observed 23 nonverbal and verbal cues displayed by ex-President Clinton during his Grand Jury Testimony in the Monica Lewinsky case. They examined a 23-minute segment of the videotape and compared this with 11 minutes of the same testimony when he answered basic questions (his name, his attorney's name, etc.). Significant differences were obtained for 19 cues. They also compared the 23-minute segment with 5 minutes of a fundraising speech to a sympathetic crowd. This time, 20 significant differences emerged. Unfortunately, this study tells us nothing about cues to deception. The comparisons between this 23-minute fragment and the other fragments are apple and orange comparisons. It is obvious that a person will show different behaviours when answering basic questions or when addressing a crowd in a fundraising speech compared to when interviewed about an alleged affair. In this respect, it might be more surprising that significant differences were found for only 19 or 20 cues and not for all 23 cues. In summary, for lie detection it is necessary that so-called comparable truths (Vrij, 2002b) are selected and compared with potentially deceptive parts of the interview.

9. Individual differences in lie detection skills. Research has demonstrated individual differences in lie detection ability, with some people being better than others. For example, in 
Mann et al.'s (2004) study the total accuracy rates for individual officers varied from a low $30 \%$ to a very high $90 \%$ (achieved by three officers, Mann, 2001).

It is not easy to explain these individual differences. The ability to detect lies is not correlated with gender and age (Ekman \& O'Sullivan 1991; Porter, Woodworth, \& Birt, 2000; Vrij \& Mann, 2001) or with lie detectors' confidence in the accuracy of their own veracity judgements (see DePaulo, Charlton, Cooper, Lindsay, \& Muhlenbruck, 1997, for a meta-analysis). However, some findings are more promising. O'Sullivan (2003) found that good lie detectors were somewhat less vulnerable to the fundamental attribution error (discussed above) than poor lie detectors. Mann et al. (2004) found a positive relationship between officers' self-reported experience in interviewing suspects and their ability to detect truths and lies. This finding has not been obtained in previous deception studies with professionals as observers (DePaulo \& Pfeifer, 1986; Ekman \& O'Sullivan, 1991; Porter et al., 2000). I believe that this is the result of how experience was measured. Other researchers, for example Ekman and O'Sullivan (1991), used 'years of job experience' as a measurement for experience. Unfortunately, they did not further define 'job experience'. It might well be that this measurement reveals little because it does not specifically relate to the amount of experience the officer has had in a relevant situation where they will attempt to detect deceit such as during interviews with suspects. There is little reason to suggest that a police officer who has worked for many years in a managerial or administrative position within the police force would have any more experience than, and hence be a better lie detector than, someone with a similar position outside the police force. Therefore perhaps unsurprisingly, Mann et al. (2004) also did not find a significant correlation either between general job experience (i.e. 'years of service') and accuracy. In other words, experience might benefit truth and lie detection, if only the relevant experience is taken into account.

In several lie detection studies the relationship between the cues people claim to pay attention to when attempting to detect deceit and their ability to distinguish between truths 
and lies was examined. In our own studies (Mann et al., 2004; Vrij \& Mann, 2001) we found that participants (police officers in both studies) who mentioned gaze aversion and fidgeting as cues to deceit achieved the lowest accuracy scores. When other researchers examined such relationships different findings emerged. For example, Ekman and O'Sullivan (1991) found that participants who mentioned both speech cues and nonverbal cues obtained higher total accuracy scores than those who mentioned only speech cues or only nonverbal cues. Anderson, DePaulo, Ansfield, Tickle, and Green's (1999) and Feeley and Young (2000) found that the more vocal cues (speech errors, speech fillers, pauses, voice) participants mentioned, the higher total accuracy they obtained. Porter et al. (2000) found no significant relationships between cues mentioned and total accuracy. Frank and Ekman (1997) reported that good lie detectors were better at spotting brief facial expressions of emotion than poor lie detectors. Such micro expressions have not been investigated in any of the other studies discussed here.

In summary, different studies reveal different outcomes, and as a result of this, a clear picture of what distinguishes a good from a poor lie detector has yet to emerge. There are at least four explanations for this lack of consistency. One explanation is that the relationships between cues mentioned and accuracy are generally weak: The correlations researchers report usually fall into the $\mathrm{r}=.20$ to $\mathrm{r}=.30$ range. Another explanation is that in different studies participants faced different lie detection situations, and therefore comparisons are difficult to make. For example, in most studies participants were requested to detect truths and lies in low-stakes situations, whereas in some studies participants were exposed to higher-stakes situations. Interestingly, in both our experiments (Mann et al., 2004; Vrij \& Mann, 2001) participants were requested to detect truths and lies told during police interviews and both studies obtained similar findings. Thirdly, perhaps lie detectors are not aware of what they pay attention to, and so lie detection could just be an intuitive skill. We (Mann et al., 2004) obtained some support for this assumption, as good lie detectors reported 
relying significantly more often on 'gut feeling' than poor lie detectors. Finally, the weak relationships between cues mentioned and ability to detect deceit and the conflicting findings between different studies may be the result of a flaw in the experimental designs used in lie detection studies. In almost all lie detection studies published to date (but see Frank and Ekman, 1997, for an exception), people's skills to detect deceit were only tested once. The fact that they were good or bad at that particular task might have been a matter of luck, and there is certainly no guarantee that those lie detectors would achieve similar levels of accuracy if they were tested a second time. A better way of examining people's ability to detect deceit and the strategies good lie detectors use is to test the same people on several occasions, and to examine those lie detectors who give a consistent performance. Particular attention could then be paid to the cues mentioned by those who are consistently good. 10. Existing interview techniques. Finally, several interview techniques promoted in police manuals hamper lie detection. For example, police detectives are sometimes advised to confront suspects with pieces of evidence they have already gathered early on in the interview (Inbau et al., 2001). This tactic is designed to show suspects that it is fruitless to remain silent and that it might be better for them to talk. This interview style will hamper lie detection. One of the difficulties for liars is that they do not know what the observer knows. They therefore do not know what they can say without running the risk of contradicting facts known to the observer. By disclosing to suspects the facts they know, police officers reduce the uncertainty for lying suspects and make lying easier for them.

Another unfortunate strategy from a lie detection perspective is if police detectives accuse suspects of lying (Inbau et al., 2001). This gives lying suspects the ideal opportunity to 'escape' from the interview situation. They might tell police detectives that they will no longer co-operate with the investigation, claiming that further interviewing is futile given the fact that the police detectives do not believe them (the suspect) anyway. Also, accusing someone might elicit the same responses in liars and truth tellers which then makes it 
impossible to distinguish between them (Bond \& Fahey, 1987; Ekman, 1985/2001). That is, when guilty suspects are accused of lying in a police interview they might become afraid of not being believed. However, innocent truthful suspects who are accused of lying might also become afraid of not being believed (Ofshe \& Leo, 1997). Because of that fear, they may show the same nervous behaviours as liars (Bond \& Fahey, 1987). This puts the lie detector in a difficult position: Should signs of fear be interpreted as signs of guilt or as signs of innocence? The behaviour doesn't provide the answer. Ekman (1985/2001) labelled this phenomenon the Othello error, after Shakespeare's play. Othello falsely accuses his wife, Desdemona, of infidelity. He tells her to confess since he is going to kill her for her treachery. Desdemona asks Cassio (her alleged lover) to be called so that he can testify her innocence. Othello tells her that he has already murdered Cassio. Realising that she cannot prove her innocence, Desdemona reacts with an emotional outburst, which Othello misinterprets as a sign of her infidelity.

\section{How to Improve Lie detection Skills}

Research regarding how to make people better lie detectors is relatively scarce, and the efficacy of several techniques which I will suggest in this section does still need to be tested in experimental research.

1. Unravel the strategies of good lie detectors. Perhaps an obvious way of improving lie detection ability is searching for good lie detectors and unravelling the strategies they use. Perhaps this knowledge can be used to make others better lie detectors? Although this sounds straightforward, it is, in fact, hazardous. First, Ekman and his colleagues who are currently searching for good lie detectors have found only a very few exceptionally good lie detectors (O'Sullivan \& Ekman, in press). Second, unravelling the strategies these good lie detectors use would not be easy either. Although good lie detectors could directly be asked which strategies they use, they probably would find this question difficult to answer, and (as discussed above) perhaps do not even know which strategy they use. Rather than asking them 
which strategies they use directly, it could be discovered in an indirect way. For example, good lie detectors could be shown videotaped clips of liars and truth tellers and could be asked to indicate which fragments of behaviour within these clips they consider relevant to their decision making. Researchers could then carefully examine these fragments. However, it is not certain whether there will be consistency amongst good lie detectors in the fragments they select. Neither is it certain that such analyses will provide any meaningful (interpretable) information. Finally, these direct or indirect ways of unravelling lie detection strategies will not work if good lie detection is primarily an intuitive skill (which cannot be ruled out, as argued above). Obviously, if good lie detection is primarily based upon intuition, teaching others to become better lie detectors would become problematic.

2. Encourage lie detectors to avoid paying attention to non-diagnostic cues. The finding that professional lie catchers have incorrect views about how liars respond suggest that they may become better lie detectors if they abolish these incorrect beliefs. Researchers have tried several methods to achieve this. In a first approach, lie detectors were given information about a few 'diagnostic cues', that is, information about some cues which the researchers believe are actually associated with deception (e.g., deTurck, Harszlak, Bodhorn, \& Texter, 1990). The problem of this method is that such cues (which will be the equivalent of Pinocchio's growing nose) do not exist. It is therefore unclear which cues need to be taught to the trainee lie detectors. A second approach is providing trainee lie detectors with outcome feedback ('correct' vs 'incorrect') regarding the truth/lie judgements they have made previously. On the basis of this information lie detectors could try to develop their own successful lie detection strategy. The benefit of such a method is that no misleading information about Pinocchio's growing nose is given. However, it is doubtful whether this 'abstract' information is sufficient enough to make people better lie detectors. Reviews of 'training studies' have indicated some, but only limited, success with both approaches (Frank \& Feeley, 2003; Vrij, 2000a). 
More ways to eliminate incorrect beliefs are possible. For example, an observer could be instructed to pay attention to 'how the speakers are saying what they have to say' (DePaulo, Lassiter, \& Stone, 1982), hereby subtly diverting the observers' attention away from misleading cues such as gaze aversion. Diverting attention can also be done in other ways. In various studies (see DePaulo, Stone, \& Lassiter, 1985a, for an overview) the 'channels' to which observers were exposed were manipulated. That is, some observers just heard an audiotape, other observers saw the full picture without sound. Another group of observers just saw people's head and shoulders, others just the body (without the head), etc.. Those studies have revealed that people become better lie detectors when they cannot see the person's face (DePaulo et al., 1985a; Wiseman, 1995). A possible explanation for this is that lie detectors are inclined to look at someone's eye movements when they are available to them, which is a misleading source of information. Those findings imply that observers could become better if they are instructed not to look at someone's face when they attempt to detect deceit. $^{7}$

Yet another way to avoid looking at non-diagnostic verbal and non-verbal cues of deception is to negate the role of humans in lie detection and use computer-based verbal and non-verbal lie detection tools. Linguistic Inquiry and Word Count (LIWC), a text analysis program that analyses written examples on a word-by-word basis, is such an example (Pennebaker, Francis, \& Booth, 2001; Pennebaker \& Graybeal, 2001). Newman, Pennebaker, Berry and Richards (2003) found that $67 \%$ of liars and truth tellers could correctly be classified with LIWC, whereas human lie detectors classified a significantly lower percentage (52\%) of the same liars and truth tellers correctly. To my knowledge, computer-based nonverbal analysis programmes are yet not available, but I know of academics in the United Kingdom who are working on such programmes and I expect such programmes to be available in the not so distant future.

3. Implicit lie detection. Another way to improve lie detection skills is by encouraging people 
to better use their already existing potential to distinguish between truths and lies. This can be achieved by asking people indirectly whether they think someone is lying (e.g., 'implicit lie detection', DePaulo, 1994; Vrij, 2001). An intriguing finding appeared in a meta-analysis of deception studies concerning confidence ratings (DePaulo et al., 1997). Regardless of whether observers judged a statement as truthful or deceptive, they had more confidence in their judgements when they had seen a truthful statement than when they had watched a deceptive statement. Apparently, something must go on in deceptive statements that observers notice. This is not enough to make them decide that the person is lying, but it is sufficient to make them insecure about the decision they make. It is their insecurity, rather than their veracity judgement, that provides valuable information about whether or not the statement was actually truthful.

In a different type of implicit lie detection study, nurses lied or told the truth about a staged event (Vrij, Edward, \& Bull, 2001b). In an attempt to simulate what liars experience in police interviews, a situation was created where the task was more difficult for the liars than for the truth tellers, and, as a result of this, liars showed signs of cognitive load such as a decrease in hand and finger movements. The interviews were videotaped and shown to police officers. Some were asked whether each of the nurses was lying (explicit lie detection), others were asked to indicate for each nurse whether s/he 'had to think hard' (implicit lie detection, they were not informed that some nurses were actually lying). Police officers could distinguish between truths and lies, but only by using the implicit method. The findings further revealed that only officers using the indirect method paid attention to the cues which actually discriminated between truth tellers and liars on the videotape, such as a decrease in hand and finger movements. In other words, the instruction to look for cues of cognitive load directed the observers' attention to more diagnostic deception cues. See DePaulo (1994) and Vrij (2001) for overviews of implicit lie detection studies.

4. Look at a combination of verbal and nonverbal cues. At present, verbal and nonverbal lie 
detection are two separate entities, with researchers either looking at speech or looking at nonverbal behaviour. I believe that looking at a combination of speech and nonverbal behaviour will yield superior results. Our own research has consistently shown that more accurate truth/lie decisions can be made when both speech content and nonverbal behaviour are taken into account instead of just speech content or just nonverbal communication (Vrij, Edward, Roberts, \& Bull, 2000; Vrij, Akehurst, Soukara, \& Bull, 2004; Vrij \& Mann, 2004). Porter and his colleagues also pointed out that looking at a combination of verbal and nonverbal cues has clear potential in deception detection (Porter \& Yuille, 1995, 1996; Porter, Yuille, \& Birt, 2001; Porter, Yuille, \& Lehman, 1999).

A recent study gives an idea of how effective informing observers about a combination of verbal and nonverbal diagnostic cues to deception combined with an implicit lie detection method could be for lie detection purposes (Vrij, Evans, Akehurst, \& Mann, in press). In a one hour training programme we taught observers (college students with no previous training in lie detection) how to make rapid (instant) assessments of the frequency of occurrence of twelve verbal and nonverbal cues which were found to be diagnostic cues to deception in literature reviews. The observers were also told how these cues were related to deception (that is, few hand and finger movements might be a sign of deceit, etc.). The observers were then shown videotaped clips of liars and truth tellers and were asked to estimate after each clip the frequency of occurrence of each of these taught diagnostic cues, and to write down these estimates (we hereby focused the observers' attention to these twelve cues). They were then asked to indicate whether or not the person in the clip was lying on the basis of their estimates (implicit lie detection). A total accuracy of $74 \%$ was found which is considerably higher than the 57\% typically found in lie detection research with laypersons as judges (Vrij, 2000a). ${ }^{8}$

5. Comparable truths. Lie detectors could be taught how to establish comparable truths and how to compare the response under investigation with the response during this comparable 
truth. To give an example, during a videotaped real-life police interview a man suspected (and later convicted) of murder was asked to describe his activities on a particular day (Vrij \& Mann, 2001). The murder suspect described his activities during the morning, afternoon and evening. Detailed analyses of the videotape revealed a sudden change in behaviour as soon as he started to describe his activities during the afternoon and evening. One possible reason for this may have been that he was lying. Evidence supported this view. Police investigations could confirm his story with regard to his morning activities, but revealed that his statement about the afternoon and evening was fabricated. In reality, he met the victim in the afternoon and killed her later on that day. In this case, we were able to make a good comparison. There are no good reasons why different behaviours would emerge while describing different parts of the day, especially when describing such a seemingly normal day as the suspect did. When such differences do emerge, they are remarkable and worth investigating. Interestingly, the question on which we based the baseline method "What did you do that particular day?" could be asked in many interviews.

6. Interviewing to detect deception. An alternative way of pursuing improvement in lie detection skills is by introducing specific interview styles. At the core of this approach is whether certain interview styles may facilitate lie detection. Unfortunately, very little is known about this, because a systematic examination of the efficacy of interview styles has attracted virtually no attention from researchers to date. In an attempt to fill this gap, we are currently conducting a series of experiments ${ }^{9}$ exploring this issue.

In an initial study, I tested the potential of a challenging information-gathering interview style versus an accusatory interview style in lie detection (Vrij, 2004). Thirty-six truth tellers and liars (college students), who were all promised a reward if they could tell a convincing story, were interviewed in three different ways: The interview started with an information-gathering interview-style (e.g., "Please tell me in as much detail as possible what happened in that room just now", Phase 1), which then developed into an accusation (e.g., 
"Just admit that you tried to fool me", Phase 2), and finally transformed back into an information-gathering interview style (e.g., "Please tell me again in as much detail as possible what happened when you were in that room just now", Phase 3). All interviews were videotaped and the behaviours of the participants were scored in detail. The most prominent differences between liars and truth tellers were expected in Phase 3. The main difference between Phases 1 and 3 was, that in Phase 3 the participants knew that they ran a serious risk of not being believed, and that this would mean that they would not be given the reward. This probably would make them more motivated in Phase 3 than in Phase 1 to tell a convincing story, and as mentioned earlier, motivated liars show more signs of deceit than unmotivated liars. Although the participants were probably also motivated in Phase 2, they were accused of not telling the truth in that phase. As mentioned above, an accusation per se will affect people's behaviour (compare Othello's example) and this 'accusation effect' (e.g., the effect an accusation has on behavioural responses) might well overshadow the 'deception effect' (e.g., the effect lying has on behavioural responses). The results supported the hypothesis and the most prominent differences between liars and truth tellers were obtained in Phase 3.

Creating a difficult situation for interviewees could be another potentially effective interview technique. As discussed above, one reason why liars give away cues of deceit is because they find it difficult to lie. Obviously, creating a difficult situation will affect both liars and truth tellers, however, if liars already find lying difficult it may well affect them more than truth tellers, resulting in more prominent differences between liars and truth tellers, and subsequently more opportunities for lie detectors to distinguish between the two.

One way of increasing difficulty in interviews is providing the evidence the lie detector has at a late stage in the interview. In a recent study (Hartwig, Granhag, Strömwall \& Vrij, 2004) participants told the truth or lied about a staged theft in a shop. Both liars and truth tellers were encouraged to tell their stories in detail. The interviewer, who had some limited knowledge about what had happened in the shop, presented this knowledge to some 
participants at a relatively early stage of the interview, and to other participants at a relatively late stage. Preliminary results indicate that lie detection was easier when the evidence was presented at a later stage. Perhaps, in that situation the liar had already reported his or her fabrication in detail and it therefore became more difficult for them to incorporate the facts the lie detector provided in their fabricated stories in a plausible and convincing way.

Another way of making an interview situation more challenging is by inviting interviewees to elaborate on what they just have said. This might well be difficult, particularly for liars. Liars might have prepared themselves about what they are going to say, but are unlikely to have prepared the amount of details which are required in extensive elaboration requests. They then face a dilemma. They could make things up spontaneously, but this is sometimes difficult. Alternatively, they could say that they do not remember anything else anymore. The latter strategy might look suspicious in case they have given a detailed account in their original answer. People rarely spontaneously recall all details they know. Therefore, providing lots of details initially followed by a total silence will look suspicious. A good strategy for liars is to fabricate a story which is in fact true, but which happened at another time than the liar claims. For example, a guilty suspect who denies involvement in the crime under investigation could claim that he was at the gym at the particularly time the crime took place. If he has been to that particular gym before he now can truthfully describe an experience at the gym. The only fabricated part in this story is when he was there. Lying about the time makes the liar vulnerable in further questioning. The interviewer could ask questions which are specifically related to the particular time the interviewee claims to have been at the gym. For example, the interviewer could ask which instructor was present at that particular time. ${ }^{10}$

Lie detectors also might make the interview situation more difficult by asking interviewees to repeat what they have said before. Liars are sometimes caught because they forgot what they previously said, they may even forget central elements of their previous 
story. Checking interviewees' memory for these central elements might therefore be a good lie detection strategy.

Yet another way of further challenging interviewees is by asking them to recall what happened in a non-chronological time order, for example in reverse order (i.e., beginning to tell what happened at the end of the event and then go back in time). Unlike truth tellers, liars tend to tell their stories in a strict chronological time order (Zaparniuk, Yuille, \& Taylor, 1995), and diverting from this order may well be too difficult for them to do.

\section{Conclusion}

I started this article by reporting research evidence regarding professional lie catchers' ability to detect deceit. I then gave numerous reasons why they make errors in their veracity judgements. I also argued that they may become better lie detectors if they avoid certain pitfalls and use some alternative interview techniques. Unfortunately, the efficacy of most of these interview styles has not yet been tested in experimental research. Such research is highly desirable, as I believe that developing efficient interview styles is the most promising way of making professionals better lie detectors. I hope that this article will encourage academics and practitioners to conduct such important research. 


\section{References}

Akehurst, L., Köhnken, G., Vrij, A., \& Bull, R. (1996). Lay persons' and police officers' beliefs regarding deceptive behaviour. Applied Cognitive Psychology, 10, 461-473.

Anderson, D. E., DePaulo, B. M., Ansfield, M. E., Tickle, J. J., \& Green, E. (1999). Beliefs about cues to deception: Mindless stereotypes or untapped wisdom? Journal of Nonverbal Behavior, 23, 67-89.

Aune, R. K., Levine, T., Ching, P., \& Yoshimoto, J. (1993). The influence of perceived source reward value and attributions of deception. Communication Research Reports, 10, 15-27.

Ben-Skakhar, G., \& Elaad, E. (2003). The validity of psychophysiological detection of information with the Guilty Knowledge test: A meta-analytic review. Journal of Applied Psychology, 88, 131-151.

Bond, C. F. and Fahey, W. E. (1987). False suspicion and the misperception of deceit. British Journal of Social Psychology, 26, 41-46.

Bond, C. F., Omar, A., Pitre, U., Lashley, B. R., Skaggs, L. M. \& Kirk, C. T. (1992). Fishy-looking liars: Deception judgment from expectancy violation. Journal of Personality and Social Psychology, 63, 969-977.

Bull, R. (in press). Training to detect deception from behavioural cues: Attempts and problems. In P. A. Granhag \& L. A. Strömwall (Eds.), Deception detection in forensic contexts. Cambridge, England: Cambridge University Press.

Bull, R., \& Rumsey, N. (1988). The social psychology of facial appearance. New York, NJ: Springer-Verlag.

Buller, D. B., \& Burgoon, J. K. (1996). Interpersonal deception theory. Communication Theory, 6, 203-242.

Burgoon, J. K., \& Buller, D. B. (1994). Interpersonal deception: III. Effects of deceit on perceived communication and nonverbal dynamics. Journal of Nonverbal Behavior, 18, 
155-184.

Burgoon, J. K., Buller, D. B., \& Guerrero, L. K. (1995). Interpersonal deception IX: Effects of social skill and nonverbal communication on deception success and detection accuracy. Journal of Language and Social Psychology, 14, 289-311.

DePaulo, B. M. (1994). Spotting lies: Can humans learn to do better? Current Directions in Psychological Science, 3, 83-86.

DePaulo, B. M., Blank, A. L., Swaim, G. W., \& Hairfield, J. G. (1992). Expressiveness and expressive control. Personality and Social Psychology Bulletin, 18, 276285.

DePaulo, B. M., Charlton, K., Cooper, H., Lindsay, J. L., \& Muhlenbruck, L. (1997). Personality and Social Psychology Review, 1, 346-357.

DePaulo, B. M., Kashy, D. A., Kirkendol, S. E., Wyer, M. M., \& Epstein, J. A. (1996). Lying in everyday life. Journal of Personality and Social Psychology, 70, 979-995.

DePaulo, B. M., \& Kirkendol, S. E. (1989). The motivational impairment effect in the communication of deception. In J. C. Yuille (Ed.), Credibility assessment (pp. 51-70). Dordrecht, the Netherlands: Kluwer.

DePaulo, B. M., Kirkendol, S. E., Tang, J., \& O'Brien, T. P. (1988). The motivational impairment effect in the communication of deception: Replications and extensions. Journal of Nonverbal Behavior, 12, 177-201.

DePaulo, B. M., Lanier, K., \& Davis, T. (1983). Detecting the deceit of the motivated liar. Journal of Personality and Social Psychology, 45, 1096-1103.

DePaulo, B. M., Lassiter, G. D., \& Stone, J. I. (1982). Attentional determinants of success at detecting deception and truth. Personality and Social Psychology Bulletin, 8, 273279.

DePaulo, B. M., LeMay, C. S., \& Epstein, J. A. (1991). Effects of importance of success and expectations for success on effectiveness at deceiving. Personality and Social 
Psychology Bulletin, 17, 14-24.

DePaulo, B. M., Lindsay, J. J., Malone, B. E., Muhlenbruck, L., Charlton, K., \& Cooper, H. (2003). Cues to deception. Psychological Bulletin, 129, 74-118.

DePaulo, B. M., \& Pfeifer, R. L. (1986). On-the-job experience and skill at detecting deception. Journal of Applied Social Psychology, 16, 249-267.

DePaulo, B. M., Stone, J. L., \& Lassiter, G. D. (1985a). Deceiving and detecting deceit. In B. R. Schenkler (Ed.), The self and social life (pp. 323-370). New York, NJ: McGraw-Hill.

DePaulo, B. M., Stone, J. I., \& Lassiter, G. D. (1985b). Telling ingratiating lies: Effects of target sex and target attractiveness on verbal and nonverbal deceptive success. Journal of Personality and Social Psychology, 48, 1191-1203.

deTurck, M. A., Harszlak, J. J., Bodhorn, D. J., \& Texter, L. A. (1990). The effects of training social perceivers to detect deception from behavioural cues. Communication Research, 38, 189-199.

Ekman, P. (1985/2001). Telling lies: Clues to deceit in the marketplace, politics and marriage. New York: W. W. Norton \& Company. (Reprinted in 1992 and 2001).

Ekman, P. (1996). Why don't we catch liars? Social Research, 63, 801-818.

Ekman, P., \& Frank, M. G. (1993). Lies that fail. In M. Lewis \& C. Saarni (Eds.), Lying and deception in everyday life (pp. 184-201). New York, NJ: Guildford Press.

Ekman, P., \& O'Sullivan, M. (1991). Who can catch a liar? American Psychologist, 46, 913-920.

Ekman, P., O'Sullivan, M., \& Frank, M. G. (1999). A few can catch a liar. Psychological Science, 10, 263-266.

Eysenck, H. J. (1984). Crime and personality. In D. J. Muller, D. E. Blackman, \& A. J. Chapman (Eds.), Psychology and Law (pp. 85-100). New York, NJ: John Wiley \& Sons.

Feeley, T. H., \& Young, M. J. (2000). The effects of cognitive capacity on beliefs 
about deceptive communication. Communication Quarterly, 48, 101-119.

Frank, M. G. \& Ekman, P. (1997). The ability to detect deceit generalizes across different types of high-stake lies. Journal of Personality and Social Psychology, 72, 1429 1439.

Frank, M. G., \& Feeley, T. H. (2003). To catch a liar: Challenges for research in lie detection. Journal of Applied Communication Research, 31, 58-75.

Gordon, N. J., Fleisher, W. L., \& Weinberg, C. D. (2002). Effective interviewing and interrogation techniques. San Diego, CA: Academic Press.

Granhag, P. A., \& Strömwall, L. A. (1999). Repeated interrogations: Stretching the deception detection paradigm. Expert Evidence: The International Journal of Behavioural Sciences in Legal Contexts, 7, 163-174.

Granhag, P. A., \& Stromwall, L. A. (2000). Effects of preconceptions on deception detection and new answers to why lie catchers often fail. Psychology, Crime, \& Law, 6, 197218.

Granhag, P. A., \& Strömwall, L. A. (2001a). Deception detection: Examining the consistency heuristic. In C. M. Breur, M. M. Kommer, J. F. Nijboer, \& J. M. Reijntjes (Eds.), New trends in criminal investigation and evidence, volume 2 (pp. 309-321). Antwerpen: Intresentia.

Granhag, P. A., \& Strömwall, L. A. (2001b). Deception detection: Interrogators' and observers' decoding of consecutive statements. The Journal of Psychology, 135, 603-620.

Granhag, P. A., Strömwall, L. A., \& Reiman, A. C. (2002). Partners in crime: How liars in collusion betray themselves. Manuscript submitted for publication.

Greuel, L. (1992). Police officers' beliefs about cues associated with deception in rape cases. In F. Lösel, D. Bender, \& T. Bliesener (Eds.), Psychology and Law: International perspectives (pp. 234-239). Berlin, Germany: Walter de Gruyter.

Gudjonsson, G. H. (2003). The psychology of interrogations and confessions: A 
handbook. Chichester, England: John Wiley.

Harrigan, J. A., \& O'Connell, D. M. (1996). Facial movements during anxiety states. Personality and Individual Differences, 21, 205-212.

Hartwig, M., Granhag, P. A., Strömwall, L. A., \& Vrij, A. (2004). Detecting deception via strategic disclosure of evidence. Manuscript in preparation.

Hess, J. E. (1997). Interviewing and interrogation for law enforcement. Reading, United Kingdom: Anderson Publishing Co.

Hirsch, A. R., \& Wolf, C. J. (2001). Practical methods for detecting mendacity: A case study. The Journal of the American Academy of Psychiatry and the Law, 29, 438-444.

Hocking, J. E., \& Leathers, D. G. (1980). Nonverbal indicators of deception: A new theoretical perspective. Communication Monographs, 47, 119-131.

Horvath, F., Jayne, B., \& Buckley, J. (1994). Differentiation of truthful and deceptive criminal suspects in behavior analysis interviews. Journal of Forensic Sciences, 39, 793-807.

Inbau, F. E., Reid, J. E., Buckley, J. P., \& Jayne, B. C. (2001). Criminal interrogation and confessions, fourth edition. Gaithersburg, Maryland: Aspen Publishers.

Kaufmann, G., Drevland, G. C. B., Wessel, E., Overskeid, G., \& Magnussen, S. (2003). The importance of being earnest: Displayed emotions and witness credibility. Applied Cognitive Psychology, 17, 21-34.

Kashy, D. A., \& DePaulo, B. M. (1996). Who lies? Journal of Personality and Social Psychology, 70, 1037-1051.

Kleiner, M. (Ed.). (2002). Handbook of polygraph testing. San Diego, CA: Academic Press.

Köhnken, G., \& Steller, M. (1988). The evaluation of the credibility of child witness statements in German procedural system. In G. Davies \& J. Drinkwater (Eds.), The child witness: Do the courts abuse children? (Issues in Criminological and Legal Psychology, no. 13) (pp. 37-45). Leicester, United Kingdom: British Psychological Society. 
LaFrance, M., \& Mayo, C. (1976). Racial differences in gaze behavior during conversations: Two systematic observational studies. Journal of Personality and Social Psychology, 33, 547-552.

Lakhani, M., \& Taylor, R. (2003). Beliefs about cues to deception in high- and lowstake situations. Psychology, Crime, \& Law, 9, 357-368.

Lane, J. D., \& DePaulo, B. M. (1999). Completing Coyne's cycle: Dysphorics' ability to detect deception. Journal of Research in Personality, 33, 311-329.

Levine, T. R., \& McCornack, S. A. (2001). Behavioral adaptation, confidence, and heuristic-based explanations of the probing effect. Human Communication Research, 27, 471-502.

Levine, T. R., Park, H. S., \& McCornack, S. A. (1999). Accuracy in detecting truths and lies: Documenting the "veracity effect". Communication Monographs, 66, 125-144.

MacLaren, V. V. (2001). A quantitative review of the Guilty Knowledge Test. Journal of Applied Psychology, 86, 674-683.

Macrae, C. N., \& Bodenhausen, G. V. (2001). Social cognition: Categorical person perception. British Journal of Psychology, 92, 239-256.

Mann, S. (2001). Suspects, lies and videotape: An investigation into telling and detecting lies in police/suspect interviews. Unpublished PhD-thesis. University of Portsmouth, Department of Psychology.

Mann, S., Vrij, A., \& Bull, R. (2002). Suspects, lies and videotape: An analysis of authentic high-stakes liars. Law and Human Behaviour, 26, 365-376

Mann, S., Vrij, A., \& Bull, R. (2004). Detecting true lies: Police officers' ability to detect deceit. Journal of Applied Psychology, 89, 137-149.

Masip, J., Garrido, E., \& Herrero, C. (in press). Facial appearance and impressions of credibility: The effects of facial babyishness and age on person perception. International Journal of Psychology. 
Masip, J., Garrido, E., \& Herrero, C. (in press). Facial appearance and judgments of credibility: The effects of facial babyishness and age on statement credibility. Genetic, Social, and General Psychology Monographs.

Masip, J., Sporer, S. L., Garrido, E., \& Herrero, C. (in press). The detection of deception with the Reality Monitoring approach: A review of the empirical evidence. Psychology, Crime, \& Law.

Mehrabian, A. (1972). Nonverbal communication. Chicago: Aldine-Atherton.

Mehrabian, A., \& Ferris, S. R. (1967). Inference of attitudes from nonverbal communication in two channels. Journal of Consulting and Clinical Psychology, 31, 248252.

Mehrabian, A., \& Wiener, M. (1967). Decoding of inconsistent communication. Journal of Personality and Social Psychology, 6, 109-114.

Meissner, C. A., \& Kassin, S. M. (2002). "He's guilty!": Investigator bias in judgments of truth and deception. Law and Human Behavior, 26, 469-480.

Moston, S., \& Engelberg, T. (1993). Police questioning techniques in tape recorded interviews with criminal suspects. Policing and Society, 3, 223-237.

Newman, M. L., Pennebaker, J. W., Berry, D., \& Richards, J. M. (2003). Lying words: Predicting deception from linguistic styles. Personality and Social Psychology Bulletin, 29, 665-675.

Ofshe, R. J. (1989). Coerced confessions: The logic of seemingly irrational action. Cultic Studies Journal, 6, 1-15.

Ofshe, R. J., \& Leo, R. A. (1997). The decision to confess falsely: Rational choice and irrational action. Denver University Law Review, 74, 979-1112.

O'Sullivan, M. (2003). The fundamental attribution error in detecting deception: The body-who-cried-wolf-effect. Personality and Social Psychology Bulletin, 29, 1316-1327. O'Sullivan, M., \& Ekman, P. (in press). The wizards of deception detection. In P. A. 
Granhag \& C. A. Strömwall (Eds.), Deception detection in forensic contexts. Cambridge: Cambridge University Press

Pennebaker, J. W., Francis, M. E., \& Booth, R. J. (2001). Linguistic Inquiry and Word Count: LIWC 2001. Mahwah, NJ: Lawrence Erlbaum.

Pennebaker, J. W., \& Graybeal, A. (2001). Patterns of natural language use: Disclosure, personality, and social integration. Current Directions in Psychological Science, $10,90-93$.

Porter, S., Woodworth, M., \& Birt, A, R. (2000). Truth, lies, and videotape: An investigation of the ability of federal parole officers to detect deception. Law and Human Behavior, 24, 643-658.

Porter, S., \& Yuille, J. C. (1995). Credibility assessment of criminal suspects through statement analysis. Psychology, Crime, \& Law, 1, 319-331.

Porter, S., \& Yuille, J. C. (1996). The language of deceit: An investigation of the verbal clues to deception in the interrogation context. Law and Human Behavior, 20, 443459.

Porter, S., Yuille, J. C., \& Birt, A. R. (2001). The discrimination of deceptive, mistaken, and truthful witness testimony. In R. Roesch, R. R. Corrado, \& R. Dempster (Eds.), Psychology in the courts: International advances in knowledge. London: Routledge.

Porter, S., Yuille, J. C., \& Lehman, D. R. (1999). The nature of real, implanted and fabricated memories for emotional childhood events: Implications for the recovered memory debate. Law and Human Behavior, 23, 517-537.

Riggio, R. E. (1986). Assessment of basic social skills. Journal of Personality and Social Psychology, 51, 649-660.

Riggio, R.E., Tucker, J., \& Throckmorton, B. (1988). Social skills and deception ability. Personality and Social Psychology Bulletin, 13, 568-577.

Riggio, R. E., Tucker, J., \& Widaman, K. F. (1987). Verbal and nonverbal cues as 
mediators of deception ability. Journal of Nonverbal Behavior, 11, 126-145.

Rozelle, R. M., \& Baxter, J. C. (1975). Impression formation and danger recognition in experienced police officers. The Journal of Social Psychology, 96, 53-63.

Steller, M., \& Köhnken, G. (1989). Criteria-Based Content Analysis. In D. C. Raskin (Ed.), Psychological methods in criminal investigation and evidence (pp. 217-245). New York, NJ: Springer-Verlag.

Stiff, J. B., Kim, H. J., \& Ramesh, C. N. (1992). Truth biases and aroused suspicion in relational deception. Communication Research, 19, 326-345.

Stiff, J. B., Miller, G. R., Sleight, C., Mongeau, P., Garlick, R., \& Rogan, R. (1989). Explanations for visual cue primacy in judgments of honesty and deceit. Journal of Personality and Social Psychology, 56, 555-564.

Strömwall, L. A., \& Granhag, P. A. (2003). Hoe to detect deception? Arresting the beliefs of police officers, prosecutors and judges. Psychology, Crime, \& Law, 9, 19-36.

Strömwall, L. A., Granhag, P. A., \& Jonsson, A. C. (2003). Deception among pairs: 'Let's say we had lunch together and hope they will swallow it'. Psychology, Crime, \& Law, 9, 109-124.

Taylor, R., \& Vrij, A. (2000). The effects of varying stake and cognitive complexity on beliefs about the cues to deception. International Journal of Police Science and Management, 3, 111-124.

Vrij, A. (1993). Credibility judgments of detectives: The impact of nonverbal behaviour, social skills and physical characteristics on impression formation. Journal of Social Psychology, 133, 601-611.

Vrij, A. (1994). The impact of information and setting on detection of deception by police detectives. Journal of Nonverbal Behaviour, 18, 117-137.

Vrij, A. (1995). Behavioral correlates of deception in a simulated police interview. Journal of Psychology, 129, 15-28. 
Vrij, A. (2000a). Detecting lies and deceit: The psychology of lying and the implications for professional practice. Chichester: John Wiley.

Vrij, A. (2000b). Telling and detecting lies as a function of raising the stakes. In C. M. Breur, M. M. Kommer, J. F. Nijboer, \& J. M. Reintjes (Eds.), New trends in criminal investigation and evidence II (pp. 699-709). Antwerpen, Belgium: Intersentia.

Vrij, A. (2001). Implicit lie detection. The Psychologist, 14, 58-60.

Vrij, A. (2002a). Deception in children: A literature review and implications for children's testimony. In H. Westcott, G. Davies, \& R. Bull (Eds.), Children's testimony (pp. 175-194). Chichester: John Wiley.

Vrij, A. (2002b). Telling and detecting lies. In N. Brace \& H. L. Westcott (Eds.), Applying Psychology (pp. 179-241). Milton Keynes, Open University.

Vrij, A. (in press, a). Criteria-Based Content Analysis: A qualitative review of the first 37 studies. Psychology, Public Policy, and Law.

Vrij, A. (in press, b). Guidelines to catch a liar. In P. A. Granhag \& C. A. Strömwall (Eds.), Deception detection in forensic contexts. Cambridge: Cambridge University Press.

Vrij, A. (2004). Challenging interviewees during interviews: The potential effects on lie detection. Manuscript submitting for publication.

Vrij, A., Akehurst, L., Soukara, R., \& Bull, R. (2004). Detecting deceit via analyses of verbal and nonverbal behavior in adults and children. Human Communication Research, 30, 8-41.

Vrij, A., Dragt, A. W., \& Koppelaar, L. (1992). Interviews with ethnic interviewees: Nonverbal communication errors in impression formation. Journal of Community and Applied Social Psychology, 2, 199-209.

Vrij, A., Edward, K., \& Bull, R. (2001a). People's insight into their own behaviour and speech content while lying. British Journal of Psychology, 92, 373-389.

Vrij, A., Edward, K., \& Bull, R. (2001b). Police officers' ability to detect deceit: The 
benefit of indirect deception detection measures. Legal and Criminological Psychology, 6, 2, 185-197.

Vrij, A., Edward, K., Roberts, K. P., \& Bull, R. (2000). Detecting deceit via analysis of verbal and nonverbal behavior. Journal of Nonverbal Behavior, 24, 239-263.

Vrij, A., Evans, H., Akehurst, L., \& Mann, S. (in press). Rapid judgements in assessing verbal and nonverbal cues: Their potential for deception researchers and lie detection. Applied Cognitive Psychology.

Vrij, A., Foppes, J. H., Volger, D. M., \& Winkel, F. W. (1992). Moeilijk te bepalen wie de waarheid spreekt: Non-verbaal gedrag belangrijkste indicator. Algemeen Politie Blad, $141,13-15$.

Vrij, A., Harden, F., Terry, J., Edward, K., \& Bull, R. (2001). The influence of personal characteristics, stakes and lie complexity on the accuracy and confidence to detect deceit. In R. Roesch, R. R. Corrado, \& R. J. Dempster (Eds.), Psychology in the courts: International advances in knowledge (pp. 289-304). London: Routlegde.

Vrij, A., \& Holland, M. (1998). Individual differences in persistence in lying and experiences while deceiving. Communication Research Reports, 15, 299-308.

Vrij, A., \& Lochun, S. (1997). Neuro-linguistic programming and the police: Worthwhile or not? Journal of Police and Criminal Psychology, 12, 25-31.

Vrij, A., \& Mann, S. (2001). Telling and detecting lies in a high-stake situation: The case of a convicted murderer. Applied Cognitive Psychology, 15, 187-203.

Vrij, A., \& Mann, S. (2003). Telling and detecting true lies: Investigating and detecting the lies of murderers and thieves during police interviews. In M. Verhallen, G. Verkaeke, P. J. van Koppen, \& J. Goethals (Eds.), Much ado about crime: Chapters on psychology and law (pp. 185-208). Brussels, Belgium: Uitgeverij Politeia.

Vrij, A., \& Mann, S. (2004). Detecting deception: The benefit of looking at a combination of behavioral, auditory and speech content related cues in a systematic manner. 
Group Discussion and Negotiation, 13, 61-79.

Vrij, A., \& Mann, S. (in press). Police use of nonverbal behavior as indicators of deception. In R. E. Riggio \& R. S. Feldman (Eds.), Applications of nonverbal communication. Mahwah, NJ: Lawrence Erlbaum Associates.

Vrij, A., \& Semin, G. R. (1996). Lie experts' beliefs about nonverbal indicators of deception. Journal of Nonverbal Behaviour, 20, 65-80.

Vrij, A., Semin, G. R., \& Bull, R. (1996). Insight in behavior displayed during deception. Human Communication Research, 22, 544-562.

Vrij, A., \& Taylor, R. (2003). Police officers' and students' beliefs about telling and detecting little and serious lies. International Journal of Police Science and Management, 5, $1-9$.

Vrij, A., \& Van Wijngaarden, J. J. (1994). Will truth come out? Two studies about the detection of false statements expressed by children. Expert Evidence: The international digest of human behaviour, science and law, 3, 78-84.

Vrij, A., \& Winkel, F. W. (1991). Cultural patterns in Dutch and Surinam nonverbal behaviour: An analysis of simulated police/citizen encounters. Journal of Nonverbal Behavior, 15, 169-184.

Vrij, A., \& Winkel, F. W. (1992a). Cross-cultural police-citizen interactions: The influence of race, beliefs and nonverbal communication on impression formation. Journal of Applied Social Psychology, 22, 1546-1559.

Vrij, A., \& Winkel, F.W. (1992b). Social skills, distorted perception and being suspect: Studies in impression formation and the ability to deceive. Journal of Police and Criminal Psychology, 8, 2-6.

Vrij, A., \& Winkel, F. W. (1994). Perceptual distortions in cross-cultural interrogations: The impact of skin color, accent, speech style and spoken fluency on impression formation. Journal of Cross-Cultural Psychology, 25, 284-296. 
Vrij, A., Winkel, F. W., \& Koppelaar, L. (1991). Interactie tussen politiefunctionarissen en allochtone burgers: twee studies naar de frequentie en het effect van aan- en wegkijken op de impressieformatie. Nederlands Tijdschrift voor de Psychologie, 46, 8-20.

Walkley, J. (1985). Reading the suspect. Police Review, 15 February.

Wallbott, H. G., \& Scherer, K. R. (1991). Stress specifics: Differential effects of coping style, gender, and type of stressor on automatic arousal, facial expression, and subjective feeling. Journal of Personality and Social Psychology, 61, 147-156.

Waltman, J. L. (1983). Nonverbal communication in interrogation: Some applications. Journal of Police and Science Administration, 11, 166-169.

Wiseman, R. (1995). The megalab truth test. Nature, 373, 391.

Yeschke, C. L. (1997). The art of investigative interviewing: A human approach to testimonial evidence.

Zaparniuk, J., Yuille, J. C., \& Taylor, S. (1995). Assessing the credibility of true and false statements. International Journal of Law and Psychiatry, 18, 343-352.

Zuckerman, M., DeFrank, R. S., Hall, J. A., Larrance, D. T., \& Rosenthal, R. (1979). Facial and vocal cues of deception and honesty. Journal of Experimental Social Psychology, 15, 378-396.

Zuckerman, M., DePaulo, B. M., \& Rosenthal, R. (1981). Verbal and nonverbal communication of deception. In L. Berkowitz (Ed.), Advances in experimental social psychology, volume 14 (1-57). New York, NJ: Academic Press.

Zulawski, D. E., \& Wicklander, D. E. (1993). Practical aspects of interview and interrogation. 


\section{Footnotes}

1. An important reason why lies remain undetected is that observers do not want to know the truth, because it is not in their best interests. We labelled this phenomenon the Ostrich effect (Vrij \& Mann, 2003). People generally appreciate the compliments made by others about their body shape, their hairstyle, the way they are dressed, their achievements, and so on. So why bother trying to discover whether those compliments are spoken in truth? More serious lies may also remain undiscovered for this same reason (Ekman, 1996; Vrij, 2000a). I don't address the Ostrich effect in this article because professional lie catchers are probably motivated to catch liars and hence it does not really apply to them.

2. Those three factors are derived from Zuckerman, DePaulo, \& Rosenthal's (1981) four factor model. In addition to the three factors mentioned in the main text, they included a fourth factor in their theoretical model, labelled 'arousal'. I left this factor out because, as Zuckerman et al. (1981) themselves acknowledge, it shows an overlap with the emotion factor. There are alternative theoretical explanations as to why liars and truth tellers sometimes respond differently. See DePaulo et al. (2003) for an overview of these theoretical considerations.

3. Participants can be told that they have to conduct an unpleasant task if they are caught out. However, clever participants will realise that researchers cannot apply these threats as participants are informed at the beginning of the experiment that they can withdraw from the study at any time.

4. Sometimes professional lie catchers tell me that they believe that eye movements are associated with deception. They then typically refer to the neurolinguistic programming (NLP) model. However, not a single scientific study has demonstrated that eye movements are related to deception in the way described in the NLP model (Vrij \& Lochun, 1997). NLP teachers who claim the opposite therefore are engaged in deceiving their pupils.

5. Hence, police officers believe that there is a relationship between consistency and veracity (Akehurst 
et al., 1996; Granhag \& Strömwall, 1999; Greuel, 1992; Strömwall \& Granhag, 2003). More specifically, they believe that consistent statements are likely to be truthful and inconsistent statements are likely to be deceptive. However, the limited research in this area has shown that there is not such a link between consistency and veracity, and, if there is a link, it is more likely to be in the opposite direction. That is, Granhag, Strömwall and Reiman (2002) found that lying pairs (i.e. two people lying in collusion) were more consistent than truth telling pairs, and that single liars and single truth tellers were equally consistent over time.

6. When the first edition of Ekman's Telling lies book appeared in 1985, not much systematic research into verbal cues to deception was published. However, this changed in the late eighties when CriteriaBased Content Analysis was introduced (Köhnken \& Steller, 1988; Steller \& Köhnken, 1989, and see Vrij, in press a, for a review of CBCA research) and in the nineties, when the Reality Monitoring system was introduced (see Vrij, 2000a, and Masip, Sporer, Garrido, \& Herrero, in press, for reviews of Reality Monitoring research). Unfortunately, Ekman does not substantially address CBCA and Reality Monitoring cues in his 2001 edition of his book.

7. A possible argument against applying this technique is that micro facial expressions of emotions which may reveal deceit (Ekman, 1985/2001) will remain unnoticed. However, they are only likely to occur when emotions are strongly and suddenly felt (Ekman, 1985/2001). Since most people do not feel strong emotions when they lie (DePaulo, Kashy, Kirkendol, Wyer, \& Epstein, 1996), most lies in daily life would remain unnoticed when lie detectors rely solely upon micro expressions of emotions. It is unknown how frequently such expressions occur in high-stakes situations such as police interviews.

8. This study differed in three aspects from traditional studies in which information about diagnostic cues is given. First, information about both nonverbal and verbal cues was given rather than information about either nonverbal cues or verbal cues. Second, information about twelve cues was 
provided rather than information about just one cue or a few cues. The latter method is misleading as it gives the impression that Pinocchio's growing nose exist. Third, an implicit lie detection method rather than an explicit lie detection method was used. Although not tested, I believe that the three aspects combined have contributed to the high accuracy scores in this study.

9. Funded by the Economic and Social Research Council (grant RES-000-23-0292).

10. I am grateful to Ron Fisher for this suggestion. 